\title{
Trade-off between offspring number and offspring size in the marine copepod Euterpina acutifrons at different food concentrations
}

\author{
C. Guisande ${ }^{1, *}$, J. Sánchez ${ }^{2}$ I. Maneiro ${ }^{1}$, A. Miranda ${ }^{2}$ \\ ${ }^{1}$ Facultad de Ciencias del Mar, Universidad de Vigo, Aptdo. 874, E-36200 Vigo, Spain \\ ${ }^{2}$ Instituto Español de Oceanografía, Centro Costero de Vigo, Aptdo. 1552, E-36280 Vigo, Spain
}

\begin{abstract}
We collected females of the marine copepod Euterpina acutifrons monthly from November 1994 to January 1996 at a station located in Ria de Vigo (Spain). A trade-off between egg size and egg number was found. As food concentration measured as mean fluorescence in the water column diminished, mean number of eggs per sac carried per female decreased, whereas mean egg size increased. An experiment carried out with adult females cultured at different food concentrations confirmed the field results, and also showed that as egg size increased, there was an increase in naupliar body length at hatching; nauplii developed faster to first copepodite stage, and net reproductive rate was higher. Therefore, the reproductive strategy of directing more energy toward offspring size rather than offspring number, at low food concentrations, clearly increases reproductive success.
\end{abstract}

KEY WORDS: Copepod - Reproduction · Food concentration

\section{INTRODUCTION}

A trade-off between egg size and egg number as food concentration varies has been observed in many zooplankton which carry eggs: in copepods (Hutchinson 1967), cladocerans (Taylor 1985, Glazier 1992, Gliwicz \& Guisande 1992, Guisande \& Gliwicz 1992) and rotifers (Guisande \& Mazuelos 1991, Galindo et al. 1993). The trade-off results in a higher reproductive investment per offspring at low food concentrations, whereas females allocate more of their reproductive resources toward increasing offspring number at high food concentrations. It has been found that one of the possible advantages of such a strategy is an increase in offspring survival under low food conditions (Burns 1988, Tessier \& Consolati 1989, Gliwicz \& Guisande 1992, Guisande \& Harris 1995). At high food concentrations, a higher reproductive success should be achieved by directing more reproductive resources into offspring number rather than offspring size.

Three important points concerning this trade-off remain unclear: (1) most of the studies have been

•E-mail: castor@uvigo.es carried out under experimental conditions, and there is little information as to whether the animals show the same pattern in the field; (2) an increase in investment per offspring may increase reproductive success more than higher survival at low food conditions, e.g. by shortening the juvenile period, or the time of first reproduction; (3) finally, it has not been shown that these trade-offs do lead to higher reproductive success.

Our aim was to determine whether females of the marine copepod Euterpina acutifrons show a trade-off between egg size and egg number, both in the field and under experimental conditions, and to determine whether this possible change in reproductive strategy maximises the reproduction output under low food conditions.

\section{METHODS}

Field study. To estimate egg size and number of eggs per sac for a field population of Euterpina acutifrons, we collected quantitative mesozooplankton samples monthly from November 1994 to January 
1996 at 1 station $39 \mathrm{~m}$ deep located in Ría de Vigo (Spain, Stn E14B; $42^{\circ} 12.8^{\prime} \mathrm{N}, 8^{\circ} 51.0^{\prime} \mathrm{W}$ ). Double oblique net hauls, from near the bottom $(34 \mathrm{~m})$ to the surface, were carried out with a Bongo net (opening diameter of $40 \mathrm{~cm}$ and $200 \mu \mathrm{m}$ mesh size). The net was provided with a 'General Oceanic' flowmeter and a depthmeter. The towing speed was kept between 1 and 2 knots. After retrieval, samples were immediately fixed with formalin (4\%) neutralised with borax. Twenty females carrying eggs, without broken sacs, were removed from samples to estimate egg size and number of eggs per sac (in November 1995 there were only 4 females carrying eggs).

Monthly data of fluorescence and temperature at the field station were taken by a Sea Bird 19 CTD cast from November 1994 to January 1996 from surface to bottom at 2 m intervals. Data for December 1994 and January 1995 were not obtained due to problems with the CTD. Water samples were taken from the surface and the bottom for CTD calibrations.

Since fluorescence is related to phytoplankton abundance (Fasham et al. 1985), we assumed that it represents, or at least is proportional to, the food available for Euterpina acutifrons. However, it is necessary to mention that fluorescence is not the best estimator of food concentration, because it does not always give a good estimation of chlorophyll concentration, and it is affected by particles that $E$. acutifrons probably cannot ingest (toxic phytoplankton or out of the range of particle sizes effectively captured by adult E. acutifrons). As depth distribution of copepods may vary during the day, Mullin (1991) used phytoplankton biomass, integrated from concentrations at several standard depths, as an indicator of food available for the copepod Calanus pacificus. For this reason, mean fluorescence of the water column was also considered as an indicator of food available to E. acutifrons in this study.

Laboratory studies. Adult female Euterpina acutifrons carrying eggs were isolated from a $2500 \mathrm{l} \mathrm{cul-}$ ture tank fed with the microalga Tetraselmis suecica (13.9 pg N cell ${ }^{-1}$, 88.9 pg C cell-1). The mean cell size (mean $\pm \mathrm{SD}, 14.35 \pm 0.56 \mu \mathrm{m}, \mathrm{n}=35$ ) is within the range of particle sizes effectively captured by adult $E$. acutifrons ( 6 to $16 \mu \mathrm{m}$; Kinne 1977).

Groups of 60 individuals were kept at $18^{\circ} \mathrm{C}$ in 11 beakers under a 12:12 h light:dark cycle at 6 different initial concentrations: $5 \times 10^{3}, 1 \times 10^{4}, 5 \times 10^{4}, 1 \times 10^{5}$. $2 \times 10^{5}$ and $3 \times 10^{5}$ cells ml $\mathrm{m}^{-1}$. The mean $\pm \mathrm{SE}$ percent of food depletion every day was $0.68 \pm 3.8 \%$. This range of food concentrations was selected because preliminary experiments showed a reduction in egg production at food concentrations higher than $3 \times 10^{5} \mathrm{cells} \mathrm{m}^{-1}$ The temperature was chosen because it is within the range (between 16 and $20^{\circ} \mathrm{C}$ ) in which egg production, individual growth rate and survival of this species are optimal (Haq 1972, Zurlini et al. 1978). The groups were retained in Plexiglas tubes with $250 \mu \mathrm{m}$ mesh bottoms that enabled nauplii to settle through to the bottom of the beaker. Each day between $09: 00$ and 11:00 h, the copepods were gently transferred to fresh phytoplankton suspension at the experimental concentration.

After $5 \mathrm{~d}$, between 6 and 8 egg sacs were removed from females for each food concentration to estimate egg number per female and mean egg size. Naupliar body lengths at hatching were estimated by isolating 5 to 7 females carrying eggs from each food concentration in individual petri dishes containing $20 \mathrm{ml}$ of the experimental food concentration. These females were inspected every $3 \mathrm{~h}$ until nauplii had hatched.

Since the combined total protein, carbohydrate and lipid content of eggs has been shown as a good indicator of reproductive investment per female in copepods (Guisande \& Harris 1995), protein, carbohydrate and lipid contents of the sacs were analysed on samples containing 2 egg sacs. Protein was analysed by the method of Lowry et al. (1951) as modified by Markwell et al. (1978). Absorbance was read at $660 \mathrm{~nm}$ and compared with a bovine serum albumin standard. Total carbohydrate was analysed by the method of Dubois et al. (1956). Absorbance was read at $485 \mathrm{~nm}$ with glucose as standard. Total lipid was determined by the sulfophosphovanillin method of Zollner \& Kirsch (1962). Absorbance was read at $530 \mathrm{~nm}$ and compared with a cholesterol standard.

Naupliar development time (period between hatching and time when nauplii reached copepodite stage I), naupliar mortality, body length of copepodite stage I, and net reproductive rate of a cohort were estimated under low food conditions $\left(5 \times 10^{3}\right.$ cells $\left.\mathrm{ml}^{-1}\right)$. Replicates of between 6 and 8 females of Euterpina acutifrons carrying eggs, which had been fed at $5 \times 10^{3}, 1 \times$ $10^{5}$ and $3 \times 10^{5}$ cells ml $^{-1}$ of Tetraselmis suecica for $5 \mathrm{~d}$ were isolated and kept at $18^{\circ} \mathrm{C}$ in individual petri dishes containing $20 \mathrm{ml}$ of experimental food concentration, which was replaced every day between 09:00 and 11:00 h. Copepods were subsequently inspected every $3 \mathrm{~h}$ to record hatching time. After hatching, all nauplii produced by each female were transferred into a new petri dish containing $40 \mathrm{ml}$ of a food concentration of $5 \times 10^{3}$ cells $\mathrm{ml}^{-1}$. Some of each group of nauplii were inspected every $3 \mathrm{~h}$ and transferred every day to fresh phytoplankton until all of them had reached copepodite stage I. The nauplii that died and therefore did not reach copepodite stage I were not taken into account in estimating the naupliar development time. The remaining groups of nauplii were used to make a life table. Three replicates each containing nauplii produced by 6 to 8 females which had been fed at $5 \times 10^{3}$. 


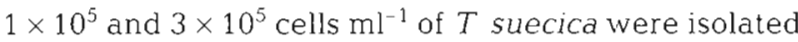
and kept at $18^{\circ} \mathrm{C}$ in individual petri dishes containing $40 \mathrm{ml}$ of $5 \times 10^{3}$ cells $\mathrm{ml}^{-1}$ Copepods were transferred every day to fresh phytoplankton, and the number of adults still alive and number of nauplii produced by females were recorded. Net reproductive rate $\left(R_{0}\right)$ of the cohorts was estimated using the following equation:

$$
R_{0}=\sum_{i=x}^{w} l_{x} b_{x}
$$

where $l_{x}$ is the mean fraction of females surviving at the beginning of each age interval, $b_{x}$ is fecundity at age $x$ (mean number of nauplii produced in each age interval by a female aged $x$ ) and $w$ is the number of age intervals.

All statistical analyses were performed with Systat (1992)

\section{RESULTS}

Fig. 1a shows mean values of temperature and fluorescence in the water column at the field station during the period of the study. Food concentration was lower in winter and higher in spring, summer and autumn. Both fluorescence $(F)$ and temperature $(T)$ were inversely correlated $\left(T=15.77-0.539 F, \mathrm{r}^{2}=0.69, F_{1,11}=\right.$ 25.2, $p<0.001)$.

The body length of females carrying eggs ranged in the field between 608 and $861 \mu \mathrm{m}$ with a mean $\pm \mathrm{SD}$ of $727.9 \pm 46.9 \mu \mathrm{m}(n=216)$. These values were similar to those obtained in the laboratory with a range between 671 and 750 and a mean \pm SD of $706.6 \pm$ $21.6 \mu \mathrm{m}(\mathrm{n}=42)$. In the field study, mean body length of females carrying eggs $(H)$ was positively correlated with fluorescence $\left(H=6.585+0.016 F, \mathrm{r}^{2}=0.57, F_{1,10}=\right.$ $25.2, \mathrm{p}=0.005)$, and negatively correlated with temperature $\left(H=938.4-14.68 T, r^{2}=0.34, F_{1,10}=5.2, p=\right.$ 0.046)

Both number of eggs per sac and egg size in Euterpina acutifrons varied in the field (Fig. 1b). The number of eggs per sac was higher in spring, summer and autumn, and lower in winter. However, an opposite pattern was found for egg size, which was higher in winter and lower in the other seasons.

Egg number was related with both temperature $\left(F_{1,10}=9.0, \mathrm{p}=0.013\right)$ and mean body length of females carrying eggs $\left(F_{1,12}=11.8, \mathrm{p}=0.005\right)$. However, a stepwise multiple regression between egg number $(E)$ as dependent variable and temperature, fluorescence, and female body length as independent variables showed that, during the period of the field study, food concentration was the main parameter governing the egg number variation in Euterpina acutifrons $(E=$ $\left.17.388+4.274 F, r^{2}=0.55, F_{1,10}=12.3, p=0.006\right)$. As expected, the number of eggs per sac increased as food concentration increased (Fig. 2a).

Egg size was not related with either temperature $\left(F_{1,10}=4.0, \mathrm{p}=0.072\right)$ nor body length of females carrying eggs $\left(F_{1,12}=2.1, p=0.171\right)$, but was significantly related with fluorescence (Fig. 2b). As food concentration diminished there was a significant increase in the mean egg size produced by females. This pattern can be interpreted as a trade-off between egg number and egg size. It seems to be confirmed by the negative relationship found between egg size and egg number, within the range between 8 and 25 eggs per sac, for this copepod species in the field (Fig. 3). Within the range between 25 and 45 eggs per sac, there was not a significant relationship between egg size and egg number with a pooled mean $\pm 2 \mathrm{SE}$ of $62.4 \pm 0.1 \mu \mathrm{m}$ (Fig. 3).

The data obtained from the experiments carried out using Tetraselmis suecica as food confirmed the trend observed in the field. A reduction of the number of eggs per sac produced by females (Fig. 4a) and an increase in egg size (Fig. 4b) were found as food con-
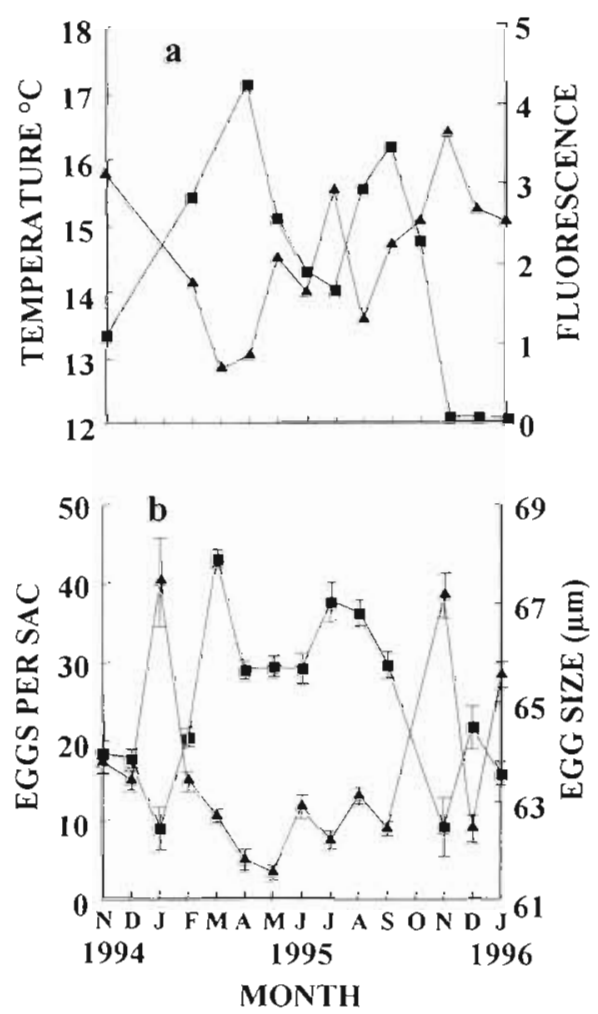

Fig. 1. (a) Mean temperature (4) and fluorescence (-) of the water column. (b) Values obtained (mean $\pm 2 \mathrm{SE}$ ) of egg size ( $\boldsymbol{\Lambda}_{\text {, in }} \mu \mathrm{m}$ ) and number of eggs per sac (ם) in Euterpina acutifrons. Data obtained from November 1994 to January 1996 at the field station monitored in this study 

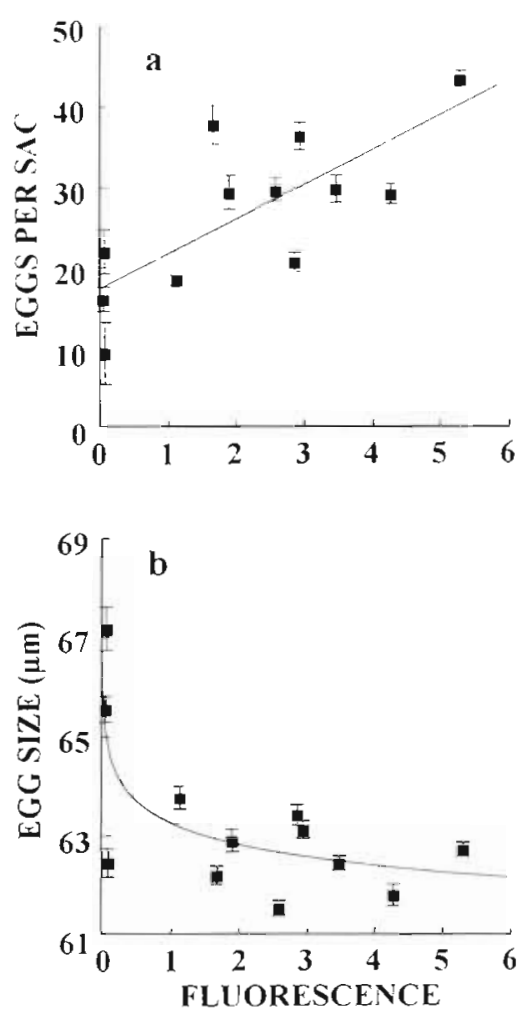

Fig. 2. Euterpina acutifrons. (a) Relationship between eggs per $\operatorname{sac}(E$, mean $\pm 2 S E, \mathrm{n}=20)$ and fluorescence $(F) . E=17.388+$ $4.274 F, \mathrm{r}^{2}=0.55, F_{1,10}=12.3, \mathrm{p}=0.006$. (b) Relationship between egg size $(S$, mean $\pm 2 S E, n=290$ to 497$)$ and fluorescence. $\ln S=4.147-0.01 \ln F_{,} r^{2}=0.48, F_{1,10}=9.3, p=0.012$

Data obtained from the field station during the study

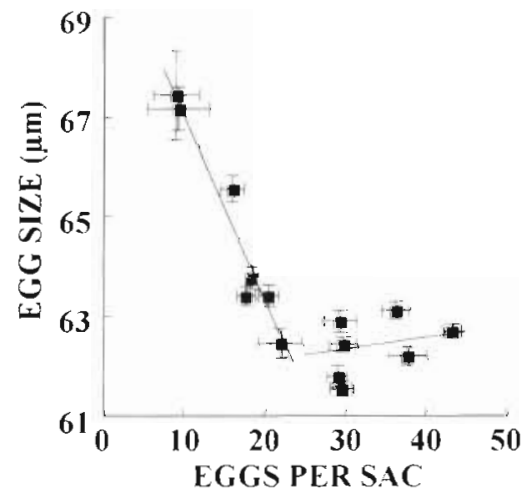

Fig. 3. Euterpina acutifrons. Relationship between egg size ( $S$, mean $\pm 2 S E, n=29010497)$ and eggs per sac $\left(E_{1}\right.$ mean $\pm 2 \mathrm{SE}$, $\mathrm{n}=20$ from data obtained in the field station. Within the range of 8 to 25 eggs per sac: $S=70.792-0.374 E_{1} r^{2}=0.94$, $F_{2}=87.3, p<0.001$ No significant differences within the range of 25 to 45 eggs per $\operatorname{sac}\left(F_{t, 5}=0.9, p=0.365\right)$

centration decreased. Also a significant relationship between egg size and egg number was obtained (Fig. 5) confirming the trade-off observed in the field. However, the reduction in the total organic content per


Fig. 4. Euterpina acutifrons. (a) Relationship between eggs per sac $(E$, mean $\pm 2 \mathrm{SE}, \mathrm{n}=14$ to 21$)$ and food concentration $(F)$. In $E=2.168+0.086 \ln F, r^{2}=0.88, F_{1,4}=30.9, p=0.005$. (b) Relationship between egg size $(S$, mean $\pm 2 \mathrm{SE}, \mathrm{n}=101$ to 170 ) and food concentration $(F)$. In $S=4.342-0.019 \ln F, r^{2}=0.79$, $F_{1,4}=15.08, \mathrm{p}=0.018$. Data obtained under experimental conditions using Tetraselmis suecica as food

sac (the combined total protein, carbohydrate and lipid content of the sac) as food concentration decreased (Fig. 6), indicated that the reduction in number of eggs per sac as food concentration decreased (Fig. 4a) was not only due to energy re-directed towards increasing egg size rather than egg number, but because the copepods were also food limited.

One of the possible advantages of the observed reproductive strategy at low food concentrations is an increase in naupliar body length at hatching as egg size increased (Fig. 7). Moreover, Table 1 shows that when nauplii were reared at a low food concentration $\left(5 \times 10^{3}\right.$ cells $\left.\mathrm{ml}^{-1}\right)$, naupliar development time was shorter (ANOVA, $F_{2.176}=32.4, \mathrm{p}<0.001$ ) and naupliar mortality was lower (ANOVA, $F_{2,67}=3.6, p=0.032$ ) as nauplii hatched from females fed with a lower food concentration. However, we did not find significant differences either in hatching success (ANOVA, $F_{2.21}=$ $2.9, p=0.079$ ), with a pooled mean \pm 2 SE of $94.3 \pm$ $3.5 \%$, or in the body lengths of copepodites when nauplii reached that stage (ANOVA, $F_{2,60}=0.06, p=$ 0.937 ) with a pooled mean $\pm 2 \mathrm{SE}$ of $327.6 \pm 3.3 \mu \mathrm{m}$. 


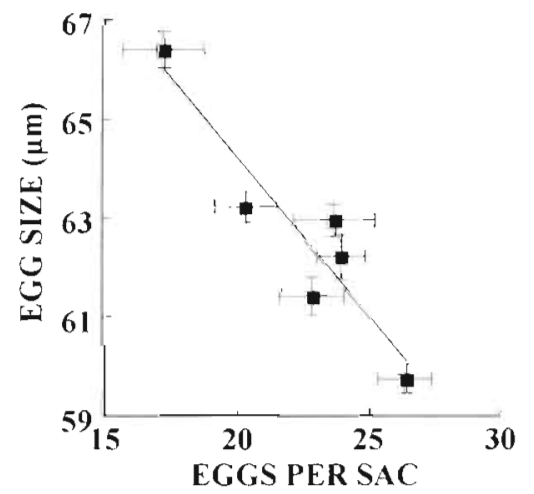

Fig. 5. Euterpina acutifrons. Relationship between egg size $(S$, mean $\pm S E, n=101$ to 170$)$ and eggs per $\operatorname{sac}(E$, mean $\pm 2 S E$, $\mathrm{n}=14$ to 21 ) obtained using Tetraselmis suecica as food. $S=$ $77.014-0.64 E, r^{2}=0.86, F_{1,4}=25.2, p=0.007$

The life table values (Table 2) obtained for each cohort of these nauplii reared at a food concentration of $5 \times 10^{3}$ cells $\mathrm{ml}^{-1}$ show that the trade-off has clear benefits for the copepods in terms of higher reproductive success. There were significant differences in net

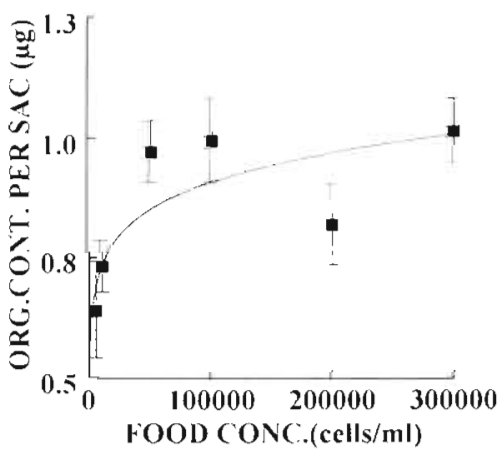

Fig. 6. Euterpina acutifrons. Relationship between total organic content per sac $1 O$ : combined total protein, carbohydrate and lipid content of the sac, mean $\pm 2 \mathrm{SE}, \mathrm{n}=4$ to 11 ) and food concentration $(F)$ obtained using Tetraselmis suecica as food. $\ln O=-1.181+0.097 \ln F_{1} \mathrm{r}^{2}=0.67, F_{1,4}=8.1, \mathrm{p}=0.047$

reproductive rate $\left(R_{0}\right)$ (ANOVA, $F_{2,6}=5.4, \mathrm{p}=0.045$ ) and, hence, population growth (Fig. 8) was higher in the cohort of nauplii hatched from eggs produced by females cultured at the lower food concentration $\left(5 \times 10^{3}\right.$ cells $\left.\mathrm{ml}^{-1}\right)$.

Table 1. Euterpina acutifrons. Values (mean \pm 2 SE and $n$ ) of hatching success, naupliar development time, naupliar mortality and body length of copepodite when nauplii reaches copepodite stage I obtained from nauplii hatched from eggs produced by females cultured at $5 \times 10^{3}, 1 \times 10^{5}$ and $3 \times 10^{3}$ cells ml-1 using Tetrasalmis suecica as food. Nauplii were reared at a food concentration of $5 \times 10^{3}$ cells $\mathrm{ml}^{-1}$

\begin{tabular}{|c|c|c|c|c|c|c|c|c|}
\hline $\begin{array}{l}\text { Food concentration } \\
\text { (cells } \mathrm{ml}^{-1} \text { ) }\end{array}$ & $\begin{array}{l}\text { Hatching } \\
\text { success }(\%)\end{array}$ & $n$ & $\begin{array}{l}\text { Naupliar } \\
\text { development time (d) }\end{array}$ & $n$ & $\begin{array}{c}\text { Naupliar } \\
\text { mortality }(\%)\end{array}$ & $\mathrm{n}$ & $\begin{array}{l}\text { Copepodite stage I } \\
\text { body length }(\mu \mathrm{m})\end{array}$ & n \\
\hline $5 \times 10^{3}$ & $98.1 \pm 2.1$ & 8 & $5.81 \pm 0.03$ & 71 & $20.0 \pm 6.2$ & 24 & $327.4 \pm 2.2$ & 65 \\
\hline $1 \times 10^{5}$ & $89.0 \pm 9.1$ & 8 & $6.12 \pm 0.09$ & 57 & $24.5 \pm 6.3$ & 21 & $327.8 \pm 2.5$ & 53 \\
\hline $3 \times 10^{5}$ & $95.9 \pm 2.8$ & 8 & $6.62 \pm 0.08$ & 51 & $31.5 \pm 6.1$ & 25 & $328.7 \pm 3.3$ & 51 \\
\hline
\end{tabular}

Table 2. Euterpina acutifrons. Life table of a cohort (mean \pm 2 SE number of nauplii produced per female) of nauplii reared at a food concentration of $5 \times 10^{3}$ cells $\mathrm{ml}^{-1}$ hatched from eggs produced by females cultured at $5 \times 10^{3}, 1 \times 10^{5}$ and $3 \times 10^{5} \mathrm{cells}^{-1} \mathrm{ml}^{-1}$ using Tetraselmis suecica as food. $R_{0}$ is net reproductive rate, $n_{x}$ is the number of copepods alive at a particular age (in days), $l_{x}$ is survival of newborn individuals to each age and $b_{x}$ is fecundity at each age (number of nauplii per female). Only females of the cohort are indicated in the life table

\begin{tabular}{|c|c|c|c|c|c|c|c|c|c|}
\hline \multirow[t]{2}{*}{ Age } & \multicolumn{3}{|c|}{5000 cells ml ${ }^{-1}$} & \multicolumn{3}{|c|}{100000 cells $\mathrm{ml}^{-1}$} & \multicolumn{3}{|c|}{300000 cells $\mathrm{ml}^{-1}$} \\
\hline & $n_{x}$ & $I_{x}$ & $b_{x}$ & $n_{3}$ & $l_{\lambda}$ & $b_{1}$ & $n_{x}$ & $I_{\mathrm{x}}$ & $b_{\mathrm{r}}$ \\
\hline $0-6$ & $6.80 \pm 1.58$ & 1 & 0 & $8.65 \pm 2.14$ & 1 & 0 & $15.27 \pm 1.50$ & 1 & 0 \\
\hline $6-12$ & $5.35 \pm 1.32$ & 0.79 & 0 & $4.72 \pm 0.18$ & 0.65 & 0 & $10.43 \pm 2.32$ & 0.68 & 0 \\
\hline $12-18$ & $3.34 \pm 0.64$ & 0.5 & 1.64 & $3.1 \pm 0.36$ & 0.38 & 1.7 & $7.07 \pm 1.02$ & 0.46 & 0.41 \\
\hline $18-24$ & $2 \pm 1.02$ & 0.29 & 10.09 & $1.94 \pm 0.94$ & 0.22 & 5.78 & $4.89 \pm 0.22$ & 0.32 & 2.73 \\
\hline $24-30$ & $1.39 \pm 0.12$ & 0.21 & 17.36 & $1.78 \pm 0.8$ & 0.2 & 12.16 & $3.17 \pm 0.5$ & 0.21 & 7.8 \\
\hline $30-36$ & $0.94 \pm 0.48$ & 0.15 & 21.94 & $0.78 \pm 0.4$ & 0.1 & 10.97 & $1.5 \pm 0.2$ & 0.1 & 5.72 \\
\hline $36-42$ & $0.94 \pm 0.48$ & 0.15 & 8.53 & $0.78 \pm 0.4$ & 0.1 & 5.69 & $0.67 \pm 0.33$ & 0.05 & 5.56 \\
\hline $42-48$ & $0.83 \pm 0.34$ & 0.13 & 8.78 & $0.67 \pm 0.33$ & 0.08 & 3.08 & $0.44 \pm 0.22$ & 0.03 & 3.67 \\
\hline $48-54$ & $0.72 \pm 0.3$ & 0.11 & 6.50 & $0.33 \pm 0.19$ & 0.05 & 4.67 & $0.33 \pm 0.15$ & 0.02 & 3.67 \\
\hline $54-60$ & $0.61 \pm 0.12$ & 0.09 & 2.83 & $0.33 \pm 0.1$ & 0.05 & 0.00 & $0.22 \pm 0.1$ & 0.02 & 0.00 \\
\hline \multirow[t]{2}{*}{$60-66$} & $0.39 \pm 0.12$ & 0.06 & 0.00 & $0.11 \pm 0.06$ & 0.01 & 0.00 & $0.11 \pm 0.08$ & 0.01 & 0.00 \\
\hline & \multicolumn{3}{|c|}{$R_{0}=14.07$} & \multicolumn{3}{|c|}{$R_{1}=6.49$} & \multicolumn{3}{|c|}{$R_{0}=3.73$} \\
\hline
\end{tabular}




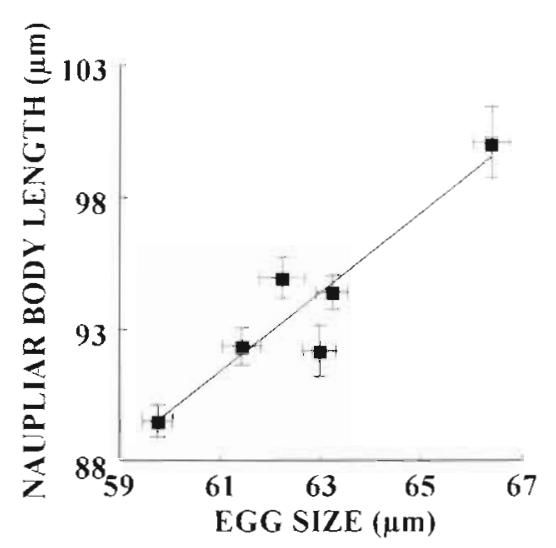

Fig. 7. Euterpina acutifrons. Relationship between naupliar body length at hatching ( $N$, mean \pm 2 SE, $n=30$ to 79$)$ and egg size $\left(S\right.$, mean $\pm \mathrm{SE}_{1} n=101$ to 170$)$ obtained using Tetraselmis suecica as food $N=0.105+1.497 S, r^{2}=0.87, F_{1,4}=27.18, p=$ 0.006

\section{DISCUSSION}

The results obtained in this study, both in the field (Fig. 3) and under experimental conditions (Fig. 5), confirmed that Euterpina acutifrons showed a trade-off between egg size and egg number as food concentration varied. This trade-off has been observed before in many copepod (Comita 1964. Hutchinson 1967. Cooney \& Gehrs 1980) and cladoceran species (Green 1954, Glazier 1992, Guisande \& Gliwicz 1992).

The relationship between egg size and egg number found in the field showed that egg size did not change at values higher than approximately 25 eggs per sac (Fig. 3). This pattern could be explained because egg size must have a minimum to assure hatching success and naupliar survival until nauplii start feeding. It was possible to observe this pattern in the field since the range of egg number per sac was higher than in the experiment carried out in the laboratory (Fig. 5).

Hutchinson (1967) was the first to point out that this trade-off could be a reproductive strategy to maximise reproductive success under low and high food concentrations. This study with Euterpina acutifrons seems to confirm Hutchinson's (1967) hypothesis. The trade-off observed in this copepod is a response to changes in the food concentration available for the animals. At high food concentrations, both in the field and under experimental conditions, females produced more but smaller eggs, but showed the opposite at low food concentrations (Figs. 2a, b \& $4 a$, b). Therefore, when the amount of food was high in the field (spring, summer and autumn; Fig 1a) females allocated most of the energy for reproduction to increasing offspring number (Fig. 1b), whereas when food concentration was low (winter; Fig. 1a), relatively more energy for repro-

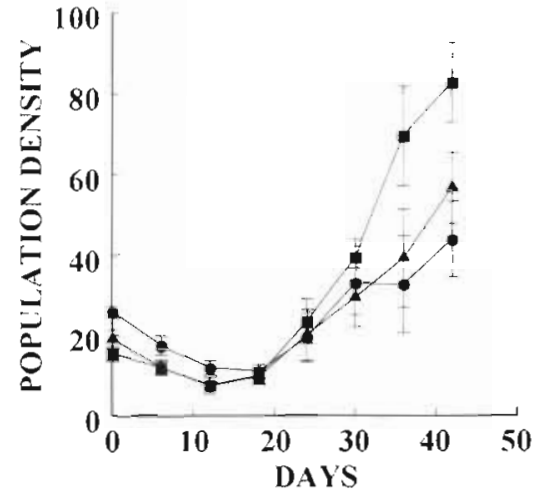

Fig. 8. Euterpina acutifrons. Evolution of population growth starting from a cohort (mean number of cohorts $\pm 2 \mathrm{SE}, \mathrm{n}=6$ to 8) of nauplii reared at a food concentration of $5 \times 10^{3}{\text { cells } \mathrm{ml}^{-1}}^{-1}$ hatched from eggs produced by females cultured at $5 \times 10^{3}(\mathbf{m})$, $1 \times 10^{5}(\mathbf{\Delta})$ and $3 \times 10^{5}(\bullet)$ cells $\mathrm{ml}^{-1}$ using Tetraselmis suecica as food

duction was allocated to increasing offspring size (Fig. 1b).

Although it has not been demonstrated in this study, it seems clear that, at high food concentrations, a higher reproductive success should be obtained by increasing reproductive investment on offspring number rather than on offspring size. However, at low food concentrations, is a higher reproductive success achieved by directing more reproductive resources toward offspring size rather than offspring number?

An increase in egg size has benefits for the offspring. Guisande \& Harris (1995) showed an increase in hatching success as egg size increased in the calanoid copepod Calanus helgolandicus. In this study with Euterpina acutifrons, although hatching success was higher in the eggs produced by females cultured at low $(5 \times$ $10^{3}$ cells $\left.\mathrm{ml}^{-1}\right)$ than at medium $\left(1 \times 10^{5}\right.$ cells $\left.\mathrm{ml}^{-1}\right)$ and high food $\left(3 \times 10^{5}\right.$ cells $\left.\mathrm{ml}^{-1}\right)$ concentrations, differences were not statistically significant. This study with $E$. acutifrons also showed that as egg size increased there was an increment in naupliar body length at hatching (Fig. 7). This relationship between egg size and neonate size has been observed in other copepod (Cooney \& Gehrs 1980, Burns 1988, Jónasdóttir 1994, Guisande \& Harris 1995) and cladoceran species (Guisande \& Gliwicz 1992). It has been shown for copepods and cladocera that as body length of neonates at hatching increases the neonates survive longer under food limitation conditions (Burns 1988, Tessier \& Consolati 1989, Gliwicz \& Guisande 1992, Guisande \& Harris 1995). This study with E. acutifrons has also shown that, at low food concentrations, naupliar development time was shorter and naupliar mortality was lower (Table 1), and total number of eggs produced per female was higher (Table 2) as nauplii hatched from larger eggs. 
Therefore, in the case of Euterpina acutifrons, with the reproductive strategy of reducing offspring number but increasing offspring size, at low food concentrations, despite the fact that the number of nauplii produced by each female is lower, net reproductive rate (Table 2) and population growth of a cohort (Fig 8) were higher as nauplii hatched from larger eggs.

The very different fecundities among the 3 groups (Table 2) could be explained because copepodite stage I must be reached at a specific body length (Table 1). Stages of development characterised by a period of growth bracketed by critical weights of entering and living the stage have been mentioned before for Euterpina acutifrons (Carlotti \& Sciandra 1989), as well as for other copepod species (Harris 1983, MCLaren 1986). If molt to copepodite stage I must occur at fixed structural body length, copepodite stage I fitness should be worse as nauplii hatch from smaller eggs This phenomenon, along with the low food concentration, could explain the low fecundities observed as nauplii hatched from smaller eggs (Table 2).

The trade-off observed could be important concerning the interactions between Euterpina acutifrons and other species. Food competitors that cannot carry out this reproductive strategy would be at a disadvantage compared with E. acutifrons, under low food conditions. On the other, it has been shown that egg size can also be affected by predation. A reduction in egg size has been observed in some zooplankton species when fish predation is high (Culver 1980, Brambilla 1982). However, under a high risk of invertebrate predation, a predator avoidance strategy should be an increase in the egg size produced by females (Lynch 1980, Dorazio \& Lehman 1983). Further studies should determine the importance of this trade-off for interspecific competition and whether this reproductive strategy can be affected by changes in predation risk.

Acknowledgements. We thank J. M. Cabanas for supplying the temperature and fluorescence data for the field station, J. J. Otero and B. Alvárez-Blazquez for their assistance during laboratory experiments, and Drs R. P. Harris and T. Wyatt and 4 anonymous referees for useful suggestions and revision of the manuscript.

\section{LITERATURE CITED}

Brambilla DJ (1982) Seasonal variation of egg size and number in a Daphnia pulex population. Hydrobiologia 203: $127-136$

Burns CW (1988) Starvation resistance among copepod nauplii and adults. Verh Int Ver Limnol 23:2087-2091

Carlotti F, Sciandra A (1989) Population dynamics model of Euterpina acutifrons (Copepoda: Harpacticoida) coupling individual growth and larval development. Mar Ecol Prog Ser 56:225-242
Comita GW (1964) The energy budget of Diaptomus siciloides, Lilljeborg. Verh Int Ver Limnol 15:646-653

Cooney JD, Gehrs CW (1980) The relationship between egg size and naupliar size in the calanoid copepod Diaptomus clavipes Schacht. Limnol Oceanogr 25:549-552

Culver D (1980) Seasonal variation in the sizes at birth and at first reproduction in cladocera. In: Kerfoot WC (ed) Evolution and ecology of zooplankton communities. University Press of New England, Hanover, NH, p 359-366

Dora7.10 RM, Lehman JT (1983) Optimal reproductive strategies in age-structured populations of zooplankton. Freshwat Biol 13:157-175

Dubois M, Gilles KA, Hamilton JK, Smith D (1956) Colorimetric method for determination of sugars and related substances. Analyt Chem 28:350-356

Fasham MJR, Platt T, Irwin B, Jones K (1985) Factors affecting the spatial pattern of the deep chlorophyll maximum in the region of the Azores front. Prog Oceanogr 14:129-165

Galindo MD, Guisande C, Toja J (1993) Reproductive investment of several rotifer species. Hydrobiologia 255/256 $317-324$

Glazier DS (1992) Effects of food, genotype, and maternal size and age on offspring investment in Daphnia magna. Ecology 73:910-926

Gliwicz ZM, Guisande C (1992) Family planning in Daphnia: resistance to starvation in offspring born to mothers grown at different food levels. Oecologia 91:463-467

Green J (1954) Size and reproduction in Daphnia magna. Proc Zool Soc Lond 124:535-545

Guisande C, Gliwicz ZM (1992) Egg size and clutch size in two Daphnia species grown at different food levels J Plankton Res 14:997-1007

Guisande C. Harris R (1995) Effect of total organic content of eggs on hatching success and naupliar survival in the copepod Calanus helgolandicus. Limnol Oceanogr 40 $476-482$

Guisande C, Mazuelos N (1991) Reproductive pattern of Brachionus calyciflorus Pallas at different food concentrations. J Plankton Res 13:279-286

Haq SM (1972) Breeding of Euterpina acutifrons, a harpacticid copepod, with special reference to dimorphic males Mar Biol 15:221-235

Harris RP (1983) The development and growth of Calanus copepodites. Limnol Oceanogr 28:142-147

Hutchinson GE (1967) A treatise on limnology. II. Introduction to lake biology and the limnoplankton. John Wiley \& Sons, New York

Jónasdóttir SH (1994) Effects of food quality on the reproductive success of Acartia tonsa and Acartia hudsonica: laboratory observations. Mar Biol 121:67-81

Kinne O (1977) Cultivation of marine organisms: water-quality management and technology. In: Kinne O (ed) Marine ecology: a comprehensive, integrated treatise on life in oceans and coastal waters. Vol III, Part 2. John Wiley \& Sons, New York, p 19-200

Lowry OH, Rosenbraugh NJ, Farr AL, Randall RJ (1951) Protein measurement with the folin phenol reagent. J Biol Chem 193:265-275

Lynch M (1980) Predation, enrichment, and the evolution of cladoceran life histories: a theoretical approach. In: Kerfoot WC (ed) Evolution and ecology of zooplankton communities. University Press of New England, Hanover, $\mathrm{NH}_{4}$ p $367-376$

Markwell MAK, Haas SM, Bieber LL, Tolbert ME (1978) A modification of de Lowry procedure to simplify protein determination in membrane and lipoprotein samples. Ann Biochem 87:206-210 
McLaren IA (1986) Is 'structural' growth of Calanus potentially exponential? Limnol Oceanogr 31:1342-1346

Mullin MM (1991) Production of eggs by the copepod Calanus pacificus in the Southern California sector of the Calıfornia Current system. CalCOFl Rep 32:65-90

Systat (1992) Systat for Windows. Systat, Inc, Evanston, IL

Taylor BE (1985) Effects of food limitation on growth and reproduction of Daphnia. Arch Hydrobiol Beih Ergebn Limnol 21:285-296

Tessier AJ, Consolati NL (1989) Variation in offspring size in

This article was submitted to the editor
Daphnia and consequences for individual fitness. Oikos 56:269-276

Zöllner N, Kirsch K (1962) Über die quantitatıve Bestimmung von Lipoiden (Mikromethode) mittels der vielen natürlichen Lipoiden (allen bekannten Plasmalipoiden) gemeinsamen Sulfophosphovanillin-Reaktion. Z Ges Exp Med 135:545-561

Zurlini G, Ferrari I, Nassogne A (1978) Reproduction and growth of Euterpina acutifrons (Copepoda: Harpacticoida) under experimental conditions. Mar Biol 46:59-64

Manuscript first received: July 10,1996

Revised version accepted: September 10, 1996 